\title{
Religious leaders weigh in on current and future embryo research
}

Embryonic stem cell research has made great strides in recent years, and religious leaders have done their best to keep pace with developments in the lab. Just last month, the Vatican condemned such research in a much anticipated bioethics document. The release of the 35-page document is the latest religious text to address two central questions in this field of study: when does the embryo go from being essentially an 'object' to a person, and what brings about this transformation?

Given the impossibility of answering these questions with any kind of scientific objectivity, it's not surprising that people reach very different conclusions on the basis of their personal morals and religious beliefs.

It was to air these divergent beliefs, rather than to find any kind of consensus, that the Progress Educational Trust, a UK nonprofit, organized a one-day conference on the ethics of embryo research. The conference, entitled Is the Embryo Sacrosanct? Multi-Faith Perspectives, was held in London in November and brought together representatives of all the major world religions, as well as several scientists and a few people of a more secular bent.

Although the discussion covered numerous aspects of embryo research and reproductive technology_including in vitro fertilization and preimplantation genetic diagnosis - the central focus was on human embryonic stem cells.
Unlike adult stem cells, ESCs can not only divide indefinitely but also transform into a wide range of cell types. As such, scientists are keen to investigate the ability of ESCs to help treat numerous diseases caused by largescale cell loss, including Alzheimer's disease, Parkinson's disease and diabetes. But they are being held back by the fact that ESCs can currently only be obtained from a five-day-old embryo, known as a blastocyst, in a process that involves its destruction.

Even though these are mainly excess embryos produced during fertility treatment, many people are unhappy about this willful destruction of embryos - and their level of objection is often determined by their religious beliefs.

\section{Differentiating views}

Most of the religions represented at the conference don't automatically grant an embryo the same rights as a person. Instead, they generally deem its transformation to personhood to occur at some point during pregnancy, often when the embryo is thought to attain a soul (known as ensoulment). This precise point not only differs between different religions but also between different denominations of the same religion.

Despite this, most religions still grant early embryos a degree of protection. Under Jewish law, an embryo is regarded as containing life in

\section{A pipe dream becomes reality}

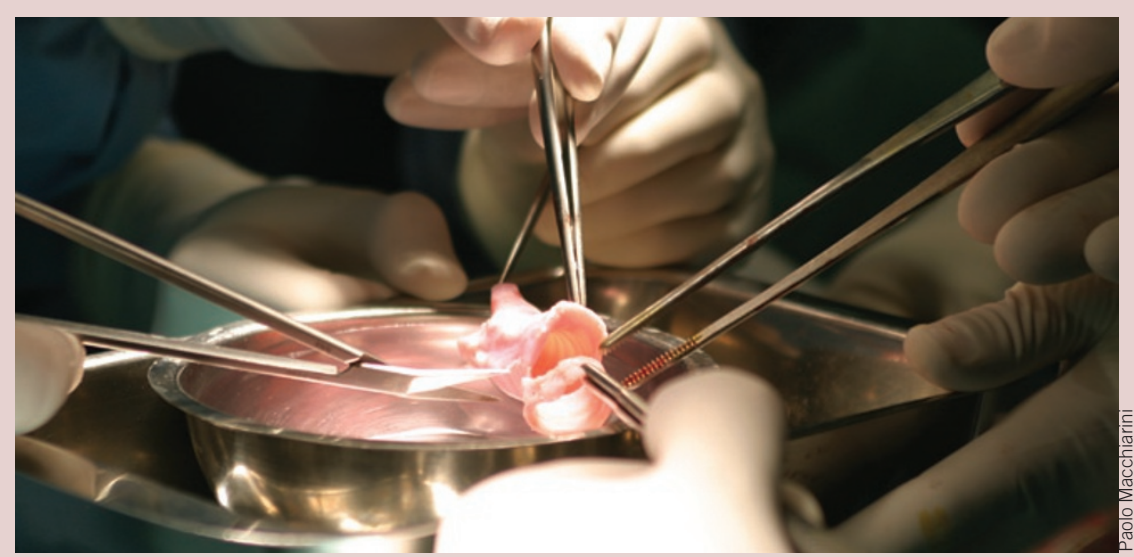

A woman who suffered airway damage from tuberculosis is breathing easy after receiving a new windpipe created with stem cell technology, researchers reported in November (Lancet 372, 2023-2030; 2008).

Paolo Macchiarini of the University of Barcelona and his collaborators stripped the living cells from a donor's trachea and seeded the tissue scaffolding with stem cells taken from the recipient's bone marrow. The engineered trachea (pictured) was therefore compatible with the recipient's immune system, lowering the chances of tissue rejection once transplanted. potential and should therefore be treated with the utmost care and attention. For a Muslim, aborting an embryo after ensoulment, which is deemed to occur at some point between 40 and 120 days after conception, is considered murder, according to representatives of this faith at the London meeting.

Offering a Christian perspective, Lee Rayfield, Anglican Bishop of Swindon and a member of the UK government's Gene Therapy Advisory Committee, made the distinction between the gradualist and absolutist positions. The gradualist position is held by the mainstream Church of England and maintains that an embryo younger than 14 days cannot be considered a person, whereas the absolutist position maintains than an embryo is a person from the moment of conception.

Such an absolutist position is held by the mainstream Roman Catholic Church, which maintains that the human embryo is morally inviolable and that it is a sin to destroy it. This is despite that fact that the Catholic Church has never officially defined at what point ensoulment takes place.

"What has been constant in the Catholic tradition $[\ldots]$ is the moral attitude of respect for human life from conception," says David Jones, professor of bioethics at St. Mary's University College, London.

But John Harris, professor of bioethics at the University of Manchester, counters that during natural reproduction embryos are also lost: "the willful creation and sacrifice of embryos is an inescapable and inevitable part of all reproduction." At the meeting Harris said that "Everybody sitting in this room is here over the dead bodies of between three and five siblings that had to die in order that we could be born."

These kinds of debates are likely to become even more complicated and impassioned as ESC technology advances. Since 2006, a number of research groups have reported producing pluripotent ESC-like cells by reprogramming adult skin cells from mice, humans and, most recently, monkeys.

On the face of it, this development should be welcomed by those opposed to embryo research, as it offers a way to obtain ESCs without using embryos. Religious experts at the recent London meeting said, however, that new ethical questions would arise if scientists find a way to reprogram adult cells to become totipotent stem cells, with the ability to develop into a fully functioning embryo.

Jon Evans, Chichester, UK 